\title{
Aeolian processes and their effect on sandy desertification of the Qinghai-Tibet Plateau: A wind tunnel experiment
}

\author{
Xunming Wang ${ }^{\mathrm{a}, \mathrm{b}, *}$, Lili Lang ${ }^{\mathrm{a}}$, Ping Yan ${ }^{\mathrm{c}}$, Guangtao Wang ${ }^{\mathrm{b}}, \mathrm{Hui} \mathrm{Li}^{\mathrm{b}}$, Wenyong Ma ${ }^{\mathrm{a}}$, \\ Ting Hua ${ }^{b}$ \\ ${ }^{a}$ Key Laboratory of Water Cycle and Related Land Surface Processes, Institute of Geographic Sciences and Natural Resources Research, Chinese Academy of \\ Sciences, Beijing 100101, China \\ ${ }^{\mathrm{b}}$ Key Laboratory of Desert and Desertification, Cold and Arid Regions Environmental and Engineering Research Institute, Chinese Academy of Sciences, \\ Lanzhou 730000, China \\ ' State Key Laboratory of Earth Surface Processes and Resource Ecology, Beijing Normal University, Beijing 100875, China
}

\section{A R T I C L E I N F O}

\section{Article history:}

Received 20 December 2014

Received in revised form 21 March 2015

Accepted 11 December 2015

Available online 28 December 2015

\section{Keywords:}

Sandy desertification

Wind erosion

Nutrient loss

Human activity

Wind tunnel simulation

Qinghai-Tibet Plateau

\begin{abstract}
A B S T R A C T
To determine the contribution of aeolian processes to sandy desertification, we applied different wind velocities to soils from the Qinghai-Tibet Plateau that were subjected to the human activities such as wholesale destruction of vegetation. We then employed field investigations, soil sampling in the field, wind tunnel experiments, particle size analyses, and nutrient analyses. After the ground surfaces were crushed to simulate land degradation, the aeolian transport in this region varied from 0.00 to $43.49 \mathrm{~g} \mathrm{~m}^{-2} \mathrm{~s}^{-1}$ and was dependent on the particle size composition, and variation in the intensity of aeolian processes. During the aeolian processes our wind tunnel results show differences between the nutrient contents of the transported materials and those of the surface soils, and the loss of total nitrogen (TN), total carbon (TC) and total phosphorus (TP) varied between 0.00 and $8.81,0.10$ and $122.27,0.00$ and $1.14 \mathrm{~g} \mathrm{~m}^{-2}$, respectively. In addition, variations in wind velocities did not result in significant differences in the particle size fractions of the transported materials. On the Qinghai-Tibet Plateau, although an increase in human activity may trigger sandy desertification, the occurrence of sandy desertification was not significant in the early 21st century, and hence it is likely to be controlled by climate even though human impacts have undeniably exacerbated its effects.
\end{abstract}

(c) 2015 Elsevier B.V. All rights reserved.

\section{Introduction}

Aeolian processes are the key forces of erosion, transportation, and deposition affecting surface soils in arid and semi-arid regions (Breshears et al., 2003; Field et al., 2012; Shao, 2008), and these processes are also a fundamental driver of sandy desertification (e.g., Schlesinger et al., 1990; Wang, 2013; Wang et al., 2013). However, sandy desertification also occurs in humid and semihumid regions, where the annual precipitation is $>450 \mathrm{~mm}$ and there are high intensities of aeolian processes. For example, in some regions of southern China where the annual precipitation is $>1000 \mathrm{~mm}$, rapid sandy desertification has occurred due to aeolian processes (Cui, 1998; Zhu, 1986; Zhu and Cui, 1996). Due to the poor structure of surface soils, tillage and trampling by animals, sandy

\footnotetext{
* Corresponding author at: Key Laboratory of Water Cycle and Related Land Surface Processes, Institute of Geographic Sciences and Natural Resources Research, Chinese Academy of Sciences, Beijing 100101, China.

E-mail addresses: xunming@lzb.ac.cn, xunming@igsnrr.ac.cn (X. Wang).
}

desertification has also been triggered by aeolian processes in other humid and semi-humid regions (e.g., Lavee et al., 1998). During aeolian processes, fine particles containing nutrient components such as nitrogen (N), carbon (C), and phosphorus (P) (Larney et al., 1998; Leys and McTainsh, 1994) are eroded, transported, and deposited far from the source region (Alfaro, 2008; Li et al., 2008, 2009; Lyles, 1988). Therefore, aeolian processes play an important role in determining the physical and chemical properties of soils (Field et al., 2010; Lyles and Tatarko, 1986). These processes can cause land degradation such as desertification (Gibbens et al., 1983; Okin et al., 2006; Peters et al., 2007), and they are also important to other terrestrial and marine ecological systems (Okin et al., 2008; Park and Jeong, 2008; Ravi et al., 2010; Uno et al., 2009; Webb et al., 2013).

During aeolian processes, particles are transported from the soil surface by creep (particles of $>500 \mu \mathrm{m}$ in diameter), saltation $(20-500 \mu \mathrm{m})$, and suspension $(<20 \mu \mathrm{m})$ (Bagnold, 1941). Creep and saltation processes mainly deposit particles within several meters to several hundreds of meters from the source. Erosion of these coarse particles can redistribute surface soils from shrub 


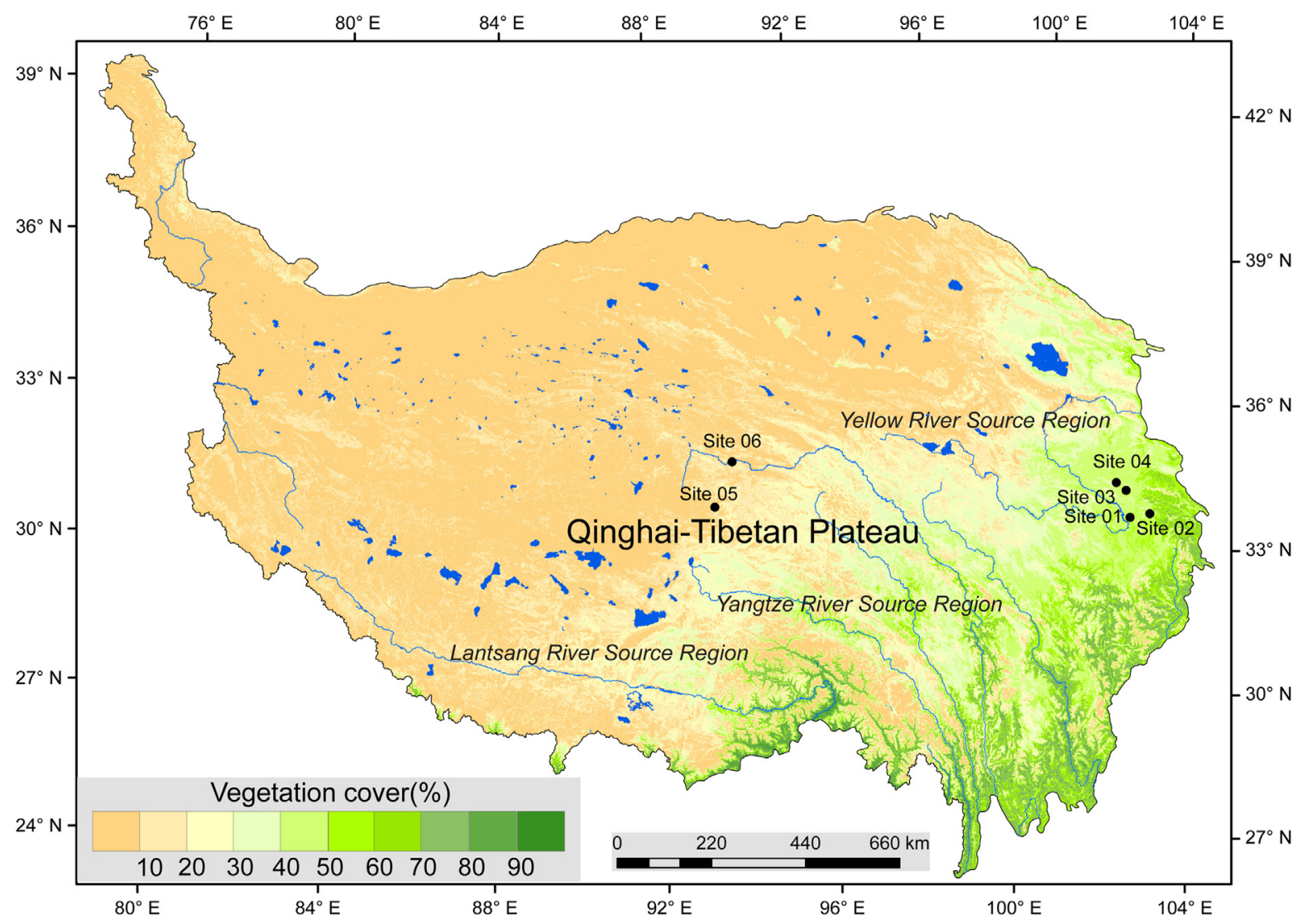

Fig. 1. Location map of sampling sites (black circles) on the Qinghai-Tibet Plateau. The location of the plateau within China is shown in the Supplementary materials (Fig. S1).

communities and open lands (Bolton et al., 1993; Reynolds et al., 1999, 2001; Schlesinger and Pilmanis, 1998), and initiate the natural succession between shrub and herbaceous communities (Gillette and Pitchford, 2004; Okin and Painter, 2004; Sterk et al., 1996). In contrast to creep and saltation, fine particles are transported by suspension and result in the surface soils becoming coarser, with decreased nutrients, reduced moisture-holding capacity (Alfaro et al., 1998; Marticorena and Bergametti, 1995), degraded plant communities, and decreased biodiversity (Alvarez et al., 2012; Christie, 1993; Muller et al., 2013; Okin and Gillette, 2001). These are key factors associated with sandy desertification (Wang, 2013). Most previous studies (e.g., Okin et al., 2006) have been concerned with aeolian processes in arid and semi-arid regions, whereas few studies have focused on the significance of nutrient migration by fine particle transportation in humid and semi-humid regions where there is a high risk of sandy desertification.

The Qinghai-Tibet Plateau, located in western China, covers an area of $2.57 \times 10^{6} \mathrm{~km}^{2}$ (Zhang et al., 2002) and has a mean elevation of over $4000 \mathrm{~m}$ above sea level. Annual precipitation is $>1000 \mathrm{~mm}$ in the southeastern area and decreases to $<20 \mathrm{~mm}$ in the northeastern area, and the Plateau includes humid, semi-humid, semi-arid, and arid climates. In addition, as the "Third Pole" of the globe, the plateau is the source of the Yangtze and Yellow rivers and other water systems in southern Asia (Cao et al., 2006; Immerzeel et al., 2010). It is also one of the potential source areas for outbreaks of global dust storms (Wang et al., 2004). Due to its fragile and vulnerable ecosystems, land degradation has occurred in this region. Over recent decades, aeolian processes and human activity (Dong, 2001; Jin et al., 2003; Li et al., 2005) have brought about sandy desertification (Fang et al., 1998; Feng et al., 2005; Han et al., 2004; Li et al., 2012), which has become important in this region where it has triggered grassland and wetland degradation (Li, 1997; Liu, 2007; Wang and Cheng, 2001; Yan et al., 2003; Zheng et al., 2012) and decreased biodiversity (Wen et al., 2011).

In recent decades, on the Qinghai-Tibet Plateau sandy desertification which was induced by human activities such as tillage, trampling by animals, and other activities such as the wholesale destruction of vegetation have greatly increased, and these occurrences, accompanied by aeolian processes that were already a serious issue (e.g., Wang et al., 2001). However, the effects of these processes on sandy desertification are still poorly understood. Although nutrient loss resulting from aeolian processes is a key mechanism of land degradation (Field et al., 2012; Schlesinger et al., 1996), and studies of nutrient loss associated with land degradation have been conducted at the landscape scale using field observations (Hobbs and Harris, 2001; Larney et al., 1998; Okin et al., 2009), few studies have employed a wind tunnel to investigate soil nutrient loss and combined these factors to address sandy desertification. Therefore, in this study we employed a wind tunnel to simulate aeolian processes and nutrient loss on land affected by human activities such as tillage, trampling by animals, and to appraise the significance of aeolian processes, nutrient loss and their effects on sandy desertification on the Qinghai-Tibet Plateau.

\section{Materials and methods}

\subsection{Study site}

Two sampling areas were selected in the study region. One area includes four sites (S01-S04) located at $33.71^{\circ}-34.30^{\circ} \mathrm{N}, 102.30^{\circ}-$ $102.96^{\circ} \mathrm{E}$, and the altitude varies between 3440 and $3480 \mathrm{~m}$ above sea level (Fig. 1). The other sites (S05 and S06) are located at 

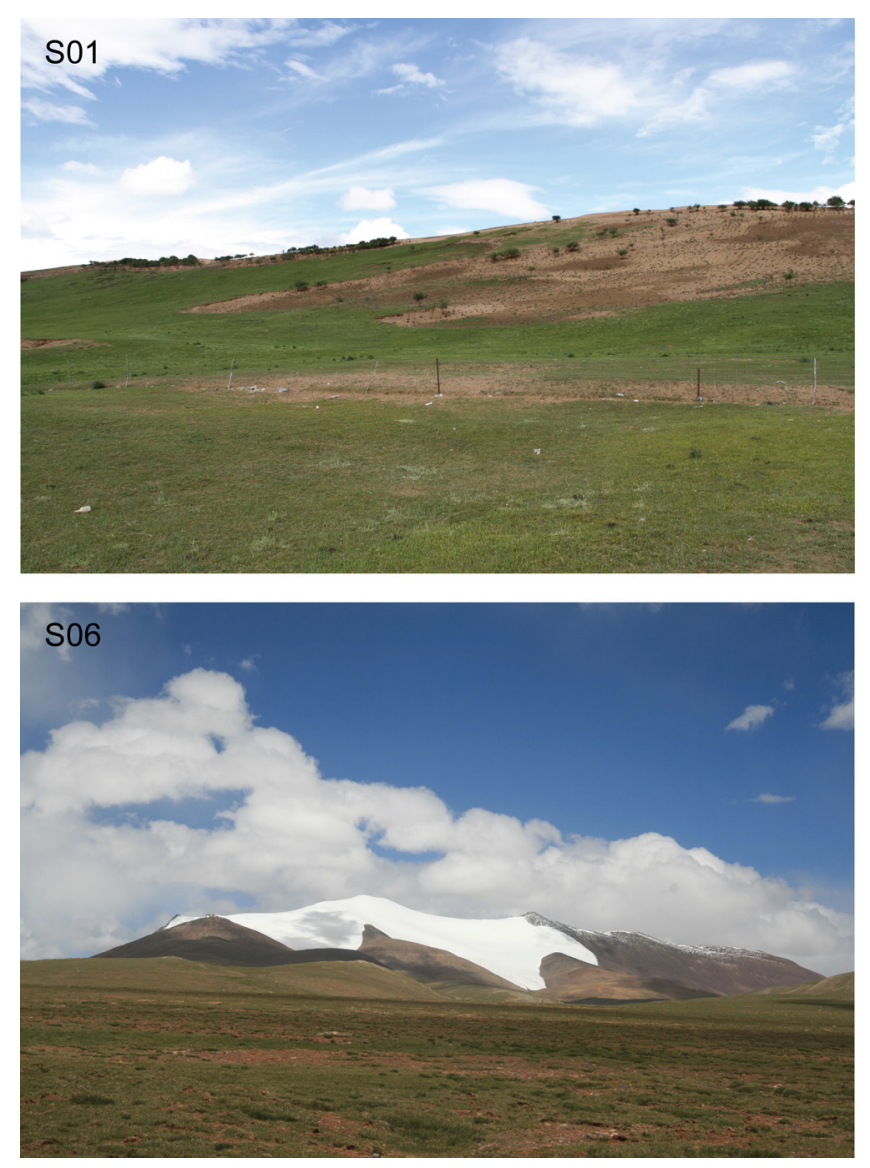

Fig. 2. The landscape of the sampling sites S01 and S06.

$33.06^{\circ} \mathrm{N}, 91.94^{\circ} \mathrm{E}$ and $34.23^{\circ} \mathrm{N}, 92.46^{\circ} \mathrm{E}$ at altitudes of $5044 \mathrm{~m}$ and $4555 \mathrm{~m}$, respectively. According to the meteorological data from the nearest weather stations around the sampling sites, sites S01 to S04 are controlled by semi-humid climate, which have an annual mean precipitation of $602 \mathrm{~mm}$ (1960-2007), an actual annual evaporation of $1269 \mathrm{~mm}$ (1967-2001), and a mean wind speed of $2.3 \mathrm{~m} \mathrm{~s}^{-1}$, and the average frequency of dust storms is four days per year (with standard visibility of $<10 \mathrm{~km}$ ). In these sites, extremely low precipitation and relative high wind speed in spring result in very low soil water content and benefit the wind erosion occurrence. Sites S05 and S06 are controlled by arid climate, which the annual mean precipitation, evaporation, mean wind speed, and the average frequency of dust storms are $281 \mathrm{~mm}$, $1629 \mathrm{~mm}, 4.0 \mathrm{~m} \mathrm{~s}^{-1}$, and 12 days per year, respectively (19572007).

At Sites S01 to S04, the vegetation cover during the growing season (May-September) was $>80 \%$, but it can decrease to $15 \%$ during the other seasons. This decrease is a consequence of intensive aeolian processes and because there are anchored, semianchored, and semi-mobile dunes scattered throughout the surfaces of the grasslands and meadows. At Sites S01-S04, most steppes already have been reclaimed for farmlands, and nearly all the surfaces have been completely crushed by the tillage processes. At Sites S05 and S06, the vegetation cover is usually $<15 \%$, even during the growing season, because of the extensively developed mobile and semi-anchored sand dunes (Fig. 2). With the great increases of the grazing sizes (sheep, goats and yaks), trampling of animals resulted in the surfaces have been significantly disturbed in both sites. The dominant vegetation species at Sites S01S04 include Eleocharis valleculosa,Blysmus sinocom pressus, Cremonthodium lineare, Cremanthodium plantaginium, Carex enervis, Carex muliensis, Juncus leucanthus, Cirsium souliei, Saussurea polycephala, Gentiana straminea, Spiraea mongolica, Spiraea alpina, Cotoneaster adpressus, Lonicera tibetica, Potentilla fruticosa, Kobresia pygmaea, Nardostachys jatamansi, Artemisia sp., Anaphalis sp., Gentiana sp., Caragana jubata, Kobresia setchwanensis, Polygonum viviparum, Leontopodium sp., Saussurea phaeantha, Gentiana aristata, Festuca ovina, and Potentilla anserina. According to the soil classification systems (e.g., Brady and Weil, 2007), the dominant surface soils are alpine meadow soil and brown meadow soil (Gong et al., 2014). The dominant vegetation species at Sites 05 and 06 include Kobresia Will, Kobresia pygmaea, Kobresia humilis, Taraxacum sp., Stipa purpurea, Roegneria thoroldiana, Poa crymophila, Carex moorcroftii, Kobresia robusta, Astragalus sp., Leontopodium nanum, Potentilla multifida, Ephedra przewalskii Stapf, Nitraria tangutorum, Calligonum mongolicum, Ceratoides lateens, Asterothamnus alyssoides, Agriophyllum squarrosum, Salsola abrotanoides, Stipa glareosa, and Ceratocarpus arenarius. The dominant soils include alpine steppe soil and desert soil (Gong et al., 2014).

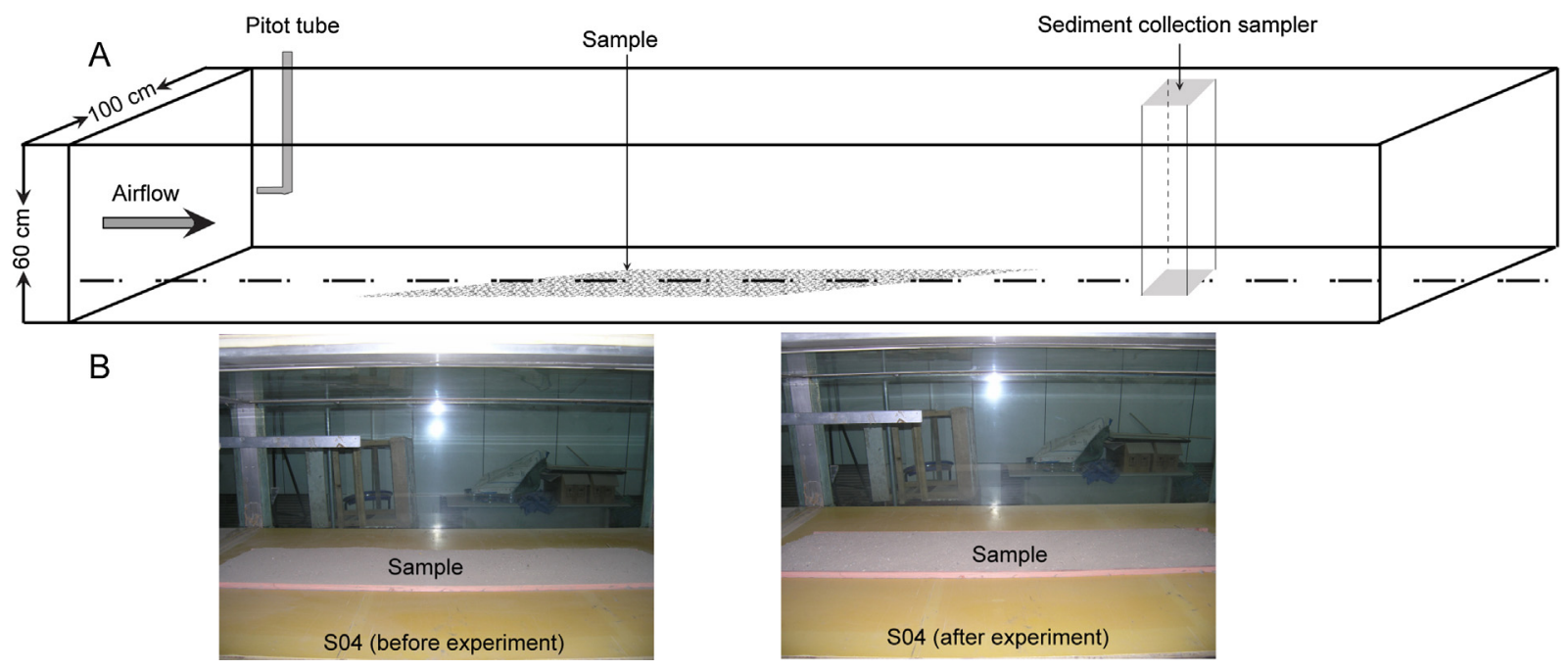

Fig. 3. (A) Schematic of the wind tunnel and (B) arrangement of samples used before and after the experiments. 
Table 1

Aeolian transport $\left(\mathrm{g} \mathrm{m}^{2} \mathrm{~s}^{-1}\right)$ under different wind velocities $\left(\mathrm{m} \mathrm{s}^{-1}\right)$ at six sites on the Qinghai-Tibet Plateau.

\begin{tabular}{|c|c|c|c|c|c|c|}
\hline Wind velocity $\left(\mathrm{m} \mathrm{s}^{-1}\right)$ & S01 & S02 & S03 & S04 & S05 & S06 \\
\hline 8 & 0.93 & 0.00 & 0.00 & 0.01 & 1.50 & 0.86 \\
\hline 10 & 4.65 & 0.01 & 0.00 & 0.02 & 8.15 & 6.43 \\
\hline 12 & 11.15 & 0.04 & 0.01 & 0.03 & 22.72 & 16.61 \\
\hline 14 & 22.77 & 0.07 & 0.04 & 0.05 & 43.71 & 48.92 \\
\hline 16 & 47.08 & 0.25 & 0.11 & 0.15 & 84.38 & 97.28 \\
\hline 18 & 77.42 & 3.35 & 0.28 & 0.30 & 133.59 & 148.47 \\
\hline 20 & 121.15 & 13.07 & 0.59 & 0.66 & 210.53 & 207.08 \\
\hline 22 & 220.8 & 43.49 & 5.09 & 1.02 & 345.82 & 301.52 \\
\hline
\end{tabular}

\subsection{Methodology}

\subsubsection{Field sampling and wind tunnel experiments}

In June 2013, we collected surface soil samples, excluding the surface vegetation litter, from the six sites. At each sampling site, because only a depth of $\sim 20 \mathrm{~cm}$ soils are disturbed by human activities, only surface soils to this depth were collected for the wind tunnel experiments and further analyses. Soils from S01, S05, and S06 were desert soils collected from graded meadows and steppes, and these soils had a dominant fraction of sand. Soils from S02, S03, and S04 were alpine meadow soils. The wind tunnel experiments were conducted at the Key Laboratory of Desert and Desertification of the Cold and Arid Regions Environmental and Engineering Research Institute, Chinese Academy of Sciences, Lanzhou, China. The blow-type, non-circulating wind tunnel has a total length of $37.8 \mathrm{~m}$ with a test section length of $16.2 \mathrm{~m}$ (Fig. 3 ). The height and width of the test section is $0.6 \mathrm{~m}$ and $1.0 \mathrm{~m}$, respectively. The free-stream wind velocity in the wind tunnel could be adjusted from 1 to $40 \mathrm{~m} \mathrm{~s}^{-1}$, as described in detail by Dong et al. (2004) and Wang et al. (2013). We used a hammer to knock the soil samples until they were crushed completely to simulate tillage and trampling by animals, and spread them over an area of $0.3 \times 1.5 \mathrm{~m}$ with about $2 \mathrm{~cm}$ thick in the experimental section of the wind tunnel. To collect the windblown materials, we installed a sand trap of $30 \mathrm{~cm}$ width (the same width as the surface sample) and $30 \mathrm{~cm}$ tall, which collected more than $95 \%$ of the transported materials (Wang et al., 2012) at a distance of $10 \mathrm{~cm}$ downwind from the sample.

During the wind tunnel experiments, the relative humidity of the atmosphere was $32-40 \%$, which is lower than during periods of collecting samples in field (53-62\%). The soil samples were airdried, and the moisture content did not exceed $1.0 \%$. We used clean wind (without saltating clouds) to assess the direct aeolian transport. During the experiments, free-stream wind velocities of $8-22 \mathrm{~m} \mathrm{~s}^{-1}$ were used at intervals of $2 \mathrm{~m} \mathrm{~s}^{-1}$, and the wind velocity of each run was calibrated by a Pitot tube (Fig. 3). The experimental duration for each wind velocity varied between 14 and 647 s. For samples from Sites S03, S04, and S05, the duration was dependent on the condition that all erodible particles at a certain wind velocity were removed from the sample surface. For samples from Sites S01, S05, and S06, because these samples were dominated by loose sands, the duration of the experiment was dependent on the amount of windblown sample collected during the wind tunnel experiments. After the aeolian transport stopped at each wind velocity, we emptied the collection sampler and weighed the total amount of collected material (balance precision, $0.001 \mathrm{~g}$ ). Because we used clean wind that was not recirculated through the wind tunnel, all material transport values at a given wind speed are expressed as cumulative values that include the materials collected at all previous wind speeds.

\subsubsection{Sample treatment and analysis}

The particle sizes were analyzed using a laser particle sizer (Mastersizer 2000; Malvern Co., Ltd., Malvern, UK; sample diameter range $0.02-2000 \mu \mathrm{m})$. Nutrient analyses included measurements of total nitrogen (total $N$ ), total carbon (totalC), and total phosphorus (total P). The concentrations of total $\mathrm{C}$ and $\mathrm{N}$ were determined using an elemental analyzer (vario Macro CNS elementar, Germany; sensing range $10 \mathrm{ppm}$ to $100 \%$ ) after packing $160.00-180.00 \mathrm{mg}$ in silver foil. Total $\mathrm{P}$ was determined by inductively coupled plasma-optical emission spectroscopy (ICPOES) (Optima-5300DV, Perkin-Elmer, USA) after digestion with a mixture of $0.003 \mathrm{~L}, 0.010 \mathrm{~L}$, and $0.0012-0.0015 \mathrm{~L}$ of $\mathrm{HNO}_{3}, \mathrm{HF}$, and $\mathrm{HClO}_{4}$, respectively. The weight of each sample was $0.05 \mathrm{~g}$, and the digested substance was diluted with distilled water to $0.010 \mathrm{~L}$ before analysis. A standard reference soil (GSS-2, Institute of Geophysical and Geochemical Exploration, Hebei, China) was used for quality assurance of the acid digestion and instrument performance. Because of the limited quantities of collected aeolian material, a few samples could not be analyzed for particle size and nutrient content. The results for the particle size fractions and the total $\mathrm{N}, \mathrm{C}$, and $\mathrm{P}$ contents under the tested wind velocities were calculated using the weight of the raw amount of aeolian transported particles acquired from the wind tunnel experiments.

Table 2

Particle size compositions (\%) of transported materials and surface soils.

\begin{tabular}{|c|c|c|c|c|}
\hline \multicolumn{2}{|c|}{ Sample code } & \multirow{2}{*}{$\frac{\text { Silt }+ \text { Clay }<20 \mu \mathrm{m}}{0.00}$} & \multirow{2}{*}{$\begin{array}{l}\text { Fine sand } 20-200 \mu \mathrm{m} \\
61.52\end{array}$} & \multirow{2}{*}{$\begin{array}{l}\text { Coarse sand } 200-2000 \mu \mathrm{m} \\
38.48\end{array}$} \\
\hline S01 & Transported materials & & & \\
\hline & Surface soils & 1.04 & 59.97 & 38.99 \\
\hline \multirow[t]{2}{*}{ S02 } & Transported materials & 43.56 & 47.27 & 9.17 \\
\hline & Surface soils & 40.03 & 53.03 & 6.94 \\
\hline \multirow[t]{2}{*}{ S03 } & Transported materials & 48.86 & 48.59 & 2.55 \\
\hline & Surface soils & 47.28 & 51.01 & 1.71 \\
\hline \multirow[t]{2}{*}{ S04 } & Transported materials & 49.56 & 39.66 & 10.78 \\
\hline & Surface soils & 55.19 & 41.25 & 3.57 \\
\hline \multirow[t]{2}{*}{ S05 } & Transported materials & 1.79 & 37.07 & 61.14 \\
\hline & Surface soils & 2.62 & 39.97 & 57.41 \\
\hline \multirow[t]{2}{*}{ S06 } & Transported materials & 0.98 & 36.79 & 62.23 \\
\hline & Surface soils & 3.17 & 40.61 & 56.23 \\
\hline
\end{tabular}



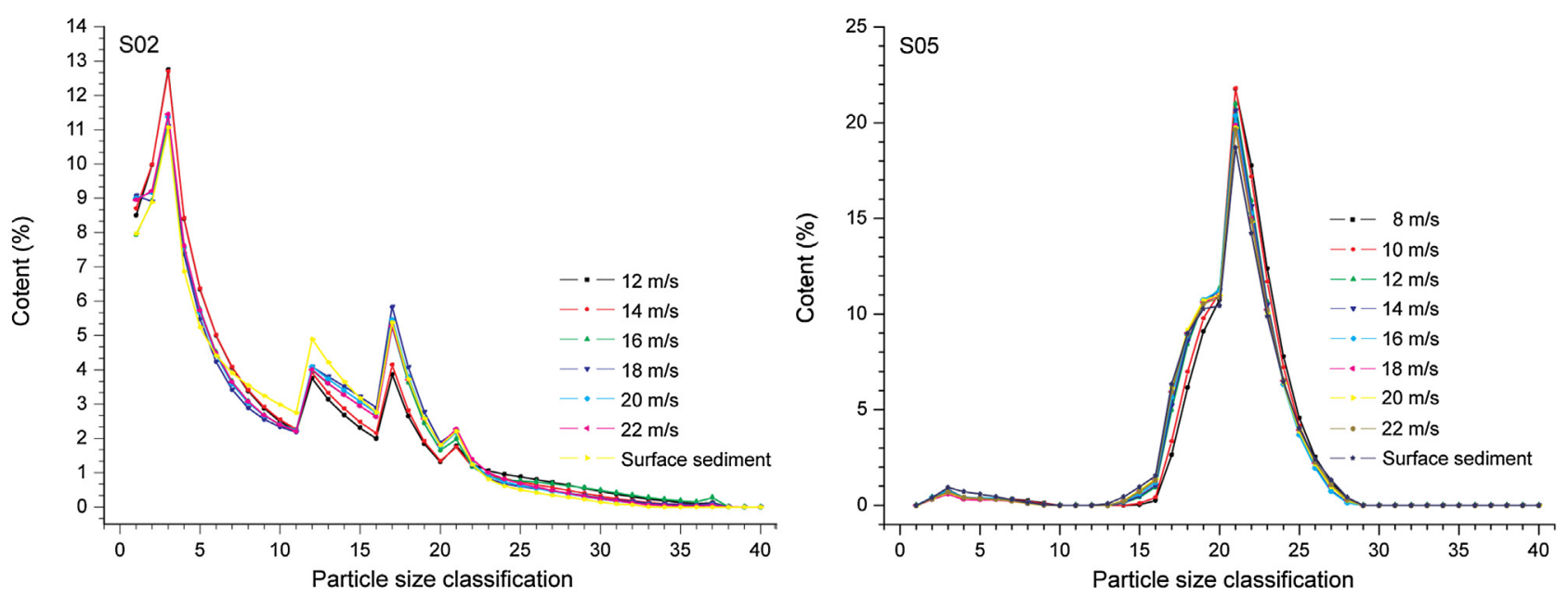

1: $<2.5,2: 2.5-5,3: 5-10,4: 10-15,5: 15-20,6: 20-25,7: 25-30,8: 30-35,9: 35-40,10: 40-45,11: 45-50,12: 50-60,13: 60-70,14: 70-80,15: 80-90,16: 90-100,17: 100-125$ 18: 125-150, 19: 150-175, 20: 175-200, 21: 200-250, 22: 250-300, 23: 300-350, 24: 350-400, 25: 400-450, 26: 450-500, 27: 500-550, 28: 550-600, 29: 600-650, 30: 650-700 31: 700-750, 32: 750-800, 33: 800-850, 34: 850-900, 35: 900-950, 36: 950-1000, 37: 1000-1250, 38: 1250-1500, 39: 1500-1750, 40: 1750-2000 $\mu \mathrm{m}$

Fig. 4. Particle size $(\mu \mathrm{m})$ distributions of transported materials and the initial surface materials under different wind velocities ( $\mathrm{m} \mathrm{s}^{-1}$ ) from two selected sites.

\section{Results and discussion}

\subsection{Aeolian transport intensity}

For the wind tunnel experiments, aeolian transport intensities under different wind velocities are summarized in Table 1. For grassland soil surfaces (i.e., S01-04) subjected to low wind velocities $\left(8-12 \mathrm{~m} \mathrm{~s}^{-1}\right)$, the aeolian transport varied between 0.00 and $0.04 \mathrm{~g} \mathrm{~m}^{-2} \mathrm{~s}^{-1}$, whereas under relatively high wind velocities $\left(14-22 \mathrm{~m} \mathrm{~s}^{-1}\right)$, aeolian transport varied between 0.04 and $43.49 \mathrm{~g} \mathrm{~m}^{-2} \mathrm{~s}^{-1}$. For the sandy surfaces subjected to 8$22 \mathrm{~m} \mathrm{~s}^{-1}$ wind velocities, the aeolian transport varied between 0.86 and $345.82 \mathrm{~g} \mathrm{~m}^{-2} \mathrm{~s}^{-1}$. These results show that higher wind velocities and sandy surfaces may produce high intensities of aeolian transport. For instance, our wind experiment results show that under mild aeolian processes (i.e., $12 \mathrm{~m} \mathrm{~s}^{-1}$ wind velocity), aeolian transport can be $4 \times 10^{5} \mathrm{~kg} \mathrm{~km}^{-2}$, and under strong aeolian processes (i.e., $22 \mathrm{~m} \mathrm{~s}^{-1}$ ), it can be $2.1 \times 10^{6} \mathrm{~kg} \mathrm{~km}^{-2}$. Assuming that the soil bulk density is $1.25 \mathrm{~g} \mathrm{~cm}^{-3}$ (Wang et al., 2000), after the surfaces are completely crushed by the tillage and trampling of animals, the depth of wind erosion during strong or mild aeolian processes may be $0.032 \mathrm{~cm}$ or $0.167 \mathrm{~cm}$, respectively.

\subsection{Particle sizes of the transported materials}

The particle size compositions of the transported materials and the surface soils (sampled before wind tunnel experiment conducting) are summarized in Table 2 . The results show some differences in particle size compositions between the transported materials and the surface soils. For example, compared to the surface soils, there are relatively high contents of coarse sand (200-2000 $\mu \mathrm{m}$ particles) in the transported materials produced from samples S02-S06 suggesting that the aeolian processes occurring in their environment may transport and accumulate coarse fractions and provide materials for dune formation (Livingstone and Warren, 1996). In addition, the aeolian processes may also erode relatively higher contents of silt and clay from the alpine meadow soil surfaces (S02-S04), resulting in coarsening of the ground soil texture, thereby triggering land degradation. In addition, under different wind velocities there were no significant differences in the particle size fractions (Fig. 4), suggesting variations in wind velocities did not significantly change the transported materials. However, because of the absence of shrubs in alpine grassland and meadows, which are necessary for coppice dune formation, the fine particles transported from the surface cannot contribute to 'islands of fertility' (Field et al., 2012; Garner and Steinberger, 1989). Instead, aeolian activity results in the spatial heterogeneity of soil resources (Ravi et al., 2009; Schlesinger and Pilmanis, 1998), which triggers grassland and meadow degradation. In particular, fine particles (i.e., $<50 \mu \mathrm{m}$ ) that contain abundant nutrients (Leys and McTainsh, 1994; Zobeck et al., 1989) are transported outside the plateau during aeolian processes in the form of dust emissions (Wang et al., 2004) that have affected ecosystems outside the plateau (Okin et al., 2008; Reynolds et al., 2001; Soderberg and Compton, 2007).

\subsection{Nutrient contents of the transported materials}

There are some differences between the contents of total N, C, and $\mathrm{P}$ of the transported materials and the surface soils (Table 3 ). Our wind tunnel results show under aeolian processes the loss of total nitrogen, total carbon and total phosphorus varied between 0.00 and $8.81,0.10$ and $122.27,0.00$ and $1.14 \mathrm{~g} \mathrm{~m}^{-2}$, respectively. After the soils were crushed, aeolian processes also induced

Table 3

Total nitrogen $(\mathrm{N})$, total carbon $(\mathrm{C})$, and total phosphorus $(\mathrm{P})$ contents of transported materials and surface soils.

\begin{tabular}{|c|c|c|c|c|c|c|c|}
\hline \multicolumn{2}{|c|}{ Nutrient composition } & \multirow{2}{*}{$\begin{array}{l}\text { S01 } \\
0.028\end{array}$} & \multirow{2}{*}{$\frac{\mathrm{S} 02}{1.148}$} & \multirow{2}{*}{$\frac{\text { S03 }}{0.457}$} & \multirow{2}{*}{$\frac{\mathrm{S} 04}{0.192}$} & \multirow{2}{*}{$\frac{\text { S05 }}{0.005}$} & \multirow{2}{*}{$\frac{\text { S06 }}{0.004}$} \\
\hline $\mathrm{N}, \%$ & Transported materials & & & & & & \\
\hline & Surface soils & 0.033 & 1.181 & 0.411 & 0.288 & 0.002 & 0.005 \\
\hline \multirow[t]{2}{*}{$\mathrm{C}, \%$} & Transported materials & 0.23 & 15.91 & 5.37 & 4.27 & 1.27 & 1.25 \\
\hline & Surface soils & 0.28 & 16.10 & 4.75 & 5.90 & 1.47 & 1.40 \\
\hline \multirow[t]{2}{*}{$\mathrm{P}, \mathrm{mg} \mathrm{kg}^{-1}$} & Transported materials & 384.5 & 1355.4 & 991.4 & 679.1 & 269.4 & 239.5 \\
\hline & Surface soils & 373.5 & 1537.0 & 1197.0 & 715.7 & 209.8 & 277.7 \\
\hline
\end{tabular}


Table 4

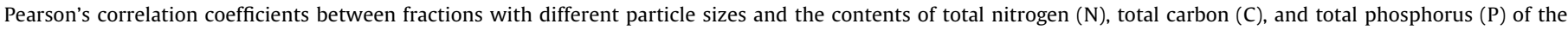
transported materials.

\begin{tabular}{|c|c|c|c|c|}
\hline & Fraction $<50 \mathrm{~mm}$ in diameter & Fraction $50 \sim 200 \mathrm{~mm}$ in diameter & Fraction $200 \sim 2000 \mathrm{~mm}$ in diameter & Mean particle size \\
\hline Total N & $0.692^{*}$ & $-0.416^{*}$ & $-0.708^{*}$ & $-0.718^{*}$ \\
\hline Total C & $0.693^{*}$ & $-0.490^{*}$ & $-0.665^{*}$ & $-0.678^{*}$ \\
\hline Total P & $0.839 *$ & $-0.491^{*}$ & $-0.866^{*}$ & $-0.870^{*}$ \\
\hline
\end{tabular}

differences between the nutritional contents of the surface materials and the transported materials. For example, for all the sites the variances (differences between the transported materials and the surface soils,\%) of the total N, C, and P with the surface soils were $2.8 \%-117.6 \%, 1.2 \%-27.6 \%$, and $5.1 \%-28.4 \%$, respectively. In addition, there were significant correlations between the fine particles $(<50 \mu \mathrm{m})$ and the contents of total C, N, and P (Table 4 ), which suggests that abundant nutrients are transported with the fine particles outside the plateau. In this region, our wind tunnel experiments show that during mild aeolian processes (i.e., $12 \mathrm{~m} \mathrm{~s}^{-1}$ wind velocity), losses of total $\mathrm{N}, \mathrm{C}$, and P were 100,4880 , and $120 \mathrm{~kg} \mathrm{~km}^{-2}$, respectively, and under strong aeolian processes (i.e., $22 \mathrm{~m} \mathrm{~s}^{-1}$ wind velocity), losses were $2540,52,340$, and $910 \mathrm{~kg}$ $\mathrm{km}^{-2}$, respectively.

3.4. Human activities and their effects on sandy desertification in the Qinghai-Tibet Plateau

The United Nations Environment Programme (UNEP) defines desertification as "land degradation in arid, semi-arid, and dry subhumid areas resulting from various factors including climatic variations and human activities" (UNEP, 1992; Wessels et al., 2008); and sandy desertification is likely to be controlled by climate change, especially by wind regimes and by geomorphological processes, even though human impacts have undeniably exacerbated their effects (Wang et al., 2006, 2007, 2008). Due to tillage and trampling of animals and under aeolian processes the main processes of sandy desertification in the Qinghai-Tibet Plateau include surface coarsening of soil texture and nutrient loess, which result in the grassland and farmland degradation, and dune reactivation ( $\mathrm{Wu}, 2009)$. For example, due to surface coarsening and the nutrient loess the dune reactivation has occurred in the eastern regions of the plateau (Feng et al., 2004; Wang et al., 2001, 2002; Li et al., 2010), and grassland and farmland degradation has appeared in nearly all regions (e.g., Dong and Chen, 2002; Liu et al., 2006; Yang et al., 2006; Zhang et al., 2006). In addition, Wang et al. (2001) showed that sandy desertification on the plateau is closely linked to human activity such as tillage and trampling by animals. Over the past decade, temperature increases have resulted in a regional climate over the Qinghai-Tibet Plateau that is suitable for cultivation and grazing over wider areas (Wang et al., 2014). In 2001, the total cultivated area and the number of large grazing animals on the southeastern plateau was $1,346,700$ ha and 3,343,000 head, and in 2010 it was 1,687,600 ha and 3,635,000 head, respectively (Qinghai Province Statistical Yearbook, Wang et al., 2014). Therefore, the increase in cultivated area and trampling by large animals, combined with the influence of aeolian processes, has led to enhanced sandy desertification (Dong et al., 2012). In this region, tillage and serious trampling by animals can completely crush the surface soils of grassland, steppe, and meadows, which resulted in large amounts of nutrients are transported away from the grassland and meadow surfaces and triggered the sandy desertification

In addition, over the past decades sandy desertification on the Qinghai-Tibet Plateau has mainly occurred in the 1970s and mid1980 s when the intensities of human activities were low (Dong and Chen, 2002; Liu et al., 2008; Zou et al., 2002). From the 1980s to the present, the annual mean wind velocity has continuously decreased on the plateau (Fig. 5), which triggered the reversal of desertification occurrence. From 2000 to 2010, although human activities have increased in this region, there was a slight decrease in the area of bare/mobile sandy land (Fig. 6). These trends suggest that although human activities have increased over recent decades, the decrease in wind velocity (Wang et al., 2014) has restrained aeolian processes, and consequently reversed the trend of sandy desertification. Therefore, on the Qinghai-Tibet Plateau, despite that recent increases in human activity resulted in nutrient loss may trigger sandy desertification, the occurrence of sandy desertification was not significant in the early 21 st century.

\section{Conclusions}

In recent decades, sandy desertification on the Qinghai-Tibet Plateau has been rapid during periods of strong aeolian processes. Our field investigations, soil sampling, wind tunnel experiments, particle size analyses, and nutrient analyses show that tillage, trampling by animals, and other human activities such as wholesale destruction of vegetation have had significant impacts on aeolian transport on the plateau, and have consequently played an important role in sandy desertification. Simulations of ground surfaces crushed by tillage and by trampling animals resulted in a change in aeolian transport from 0.00 to $345.82 \mathrm{~g} \mathrm{~m}^{-2} \mathrm{~s}^{-1}$,

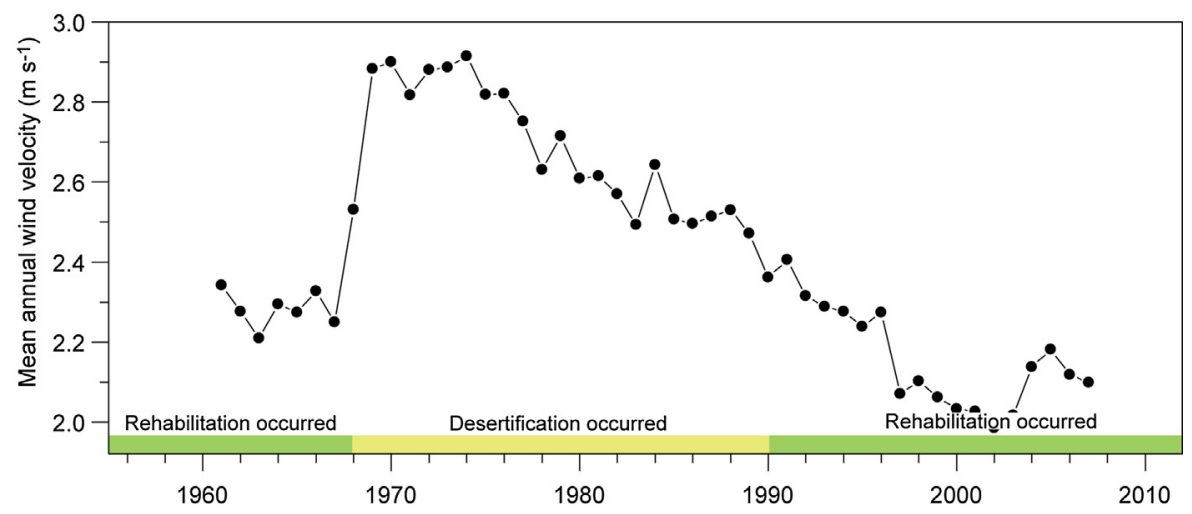

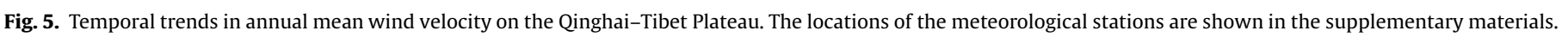



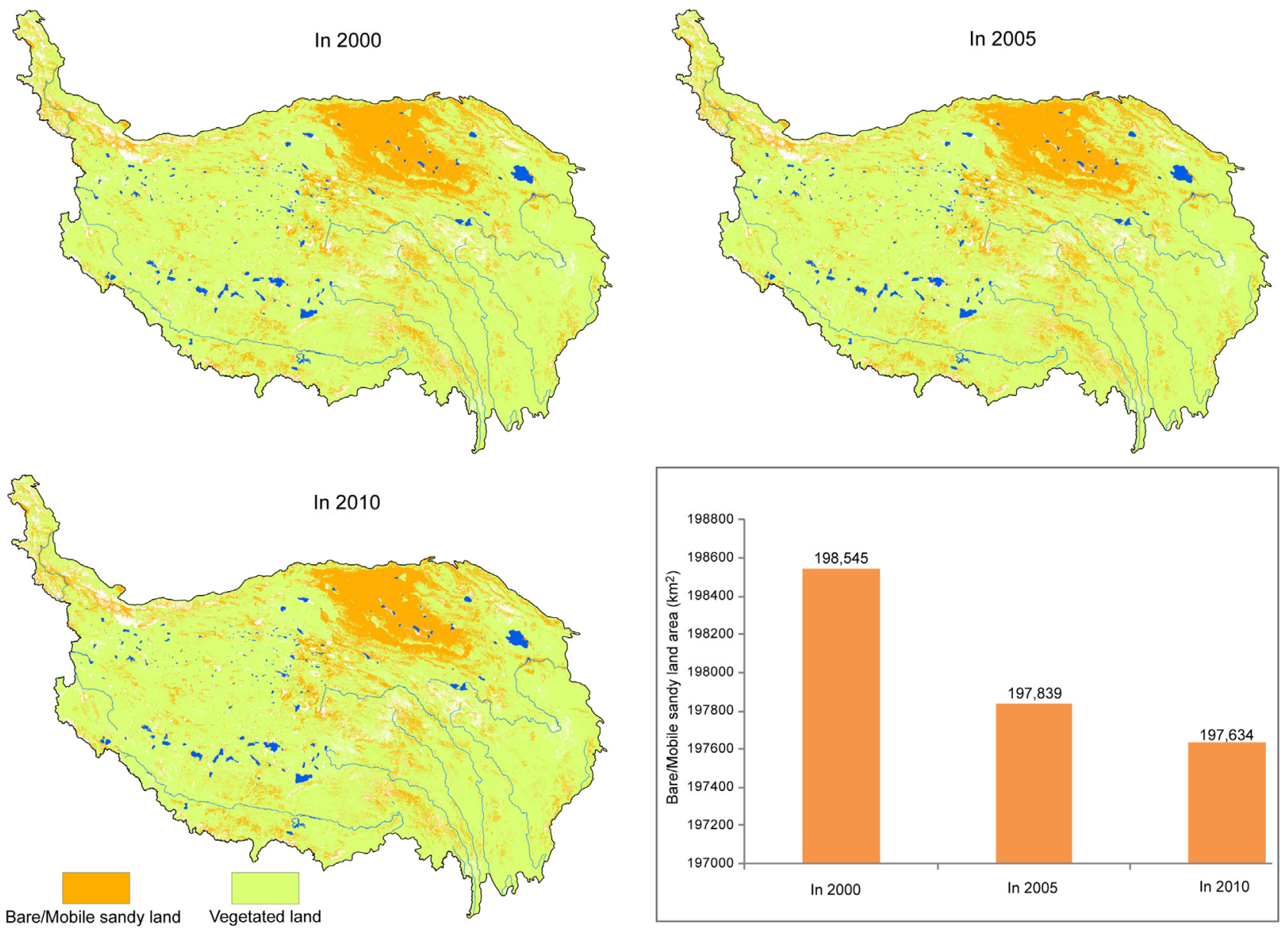

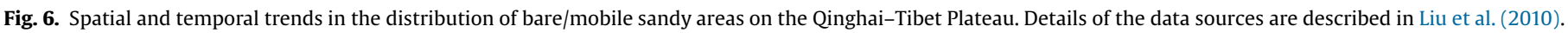

influenced by the properties and particle size compositions of the surface soils and wind velocity. During the aeolian processes, our wind tunnel experiments show that during mild aeolian processes (i.e., $12 \mathrm{~m} \mathrm{~s}^{-1}$ wind velocity), losses of total $\mathrm{N}, \mathrm{C}$, and P were 100 , 4880 , and $120 \mathrm{~kg} \mathrm{~km}^{-2}$, respectively, and under strong aeolian processes (i.e., $22 \mathrm{~m} \mathrm{~s}^{-1}$ wind velocity), losses were 2540, 52,340, and $910 \mathrm{~kg} \mathrm{~km}^{-2}$, respectively. On the Qinghai-Tibet Plateau, sandy desertification is likely to be controlled by climate even though human impacts have undeniably exacerbated its effects.

\section{Acknowledgments}

This work was supported by the National Key Project for Basic Research, "Responses of Aeolian Desertification to Global Change in the Qinghai-Tibet Plateau" (2013CB956003) and the National Science Fund for Distinguished Young Scholars of China (No. 41225001). We thank our colleagues for helpful comments.

\section{Appendix A. Supplementary data}

Supplementary data associated with this article can be found, in the online version, at http://dx.doi.org/10.1016/j.still.2015.12.004.

\section{References}

Alfaro, S.C., 2008. Influence of soil texture on the binding energies of fine mineral dust particles potentially released by wind erosion. Geomorphology 93 (3-4), 157-167.
Alfaro, S.C., Gaudichet, A., Gomes, L., Maillé, M., 1998. Mineral aerosol production by wind erosion: aerosol particle sizes and binding energies. Geophys. Res. Lett. 25, 991-994.

Alvarez, L.J., Epstein, H.E., Li, J., Okin, G.S., 2012. Aeolian process effects on vegetation communities in an arid grassland ecosystem. Ecol. Evol. 2, 809-821.

Bagnold, R.A., 1941. The Physics of Blown Sand and Desert Dunes. Methuen, London.

Bolton, H., Smith, J.L., Link, S.O., 1993. Soil microbial biomass and activity of a disturbed and undisturbed shrub-steppe ecosystem. Soil Biol. Biochem. 25, 545-552.

Brady, N.C., Weil, R., 2007. The Nature and Properties of Soils, 14th ed. Prentice Hall, New Jersey.

Breshears, D.D., Whicker, J.J., Johansen, M.P., Pinder III, J.E., 2003. Wind and water erosion and transport in semi-arid shrubland, grassland and forest ecosystems: quantifying dominance of horizontal wind-driven transport. Earth Surf. Process Landforms 1209.

Cao, J.T., Qin, D.H., Kang, E.S., Li, Y.Y., 2006. River discharge changes in the QinghaiTibet Plateau. Chin. Sci. Bull. 51, 594-600.

Christie, E.K., 1993. Ecosystem Change and Land Degradation. In: McTainsh, G.H., Boughton, W.C. (Eds.), Land Degradation Processes in Australia. LongmanCheshire, Melbourne, pp. 307-342.

Cui, S., 1998. Desertification in humid Area. Quat. Sci. 2, 173-181.

Dong, Y., 2001. Driving mechanism and status of sandy desetification in the northern Tibet plateau. J. Mt. Sci. 19, 385-391.

Dong, Y., Chen, K., 2002. Status and driving force of sandy desertification in upper reaches of Yangtze river. Resour. Environ. Yangtze Basin 11, 84-88.

Dong, Z., Hu, G., Lu, J., Yan, C., Wei, Z., 2012. Aeolian Desertification in the Source Regions of the Yangtze River and the Yellow River. Science Press, Beijing.

Dong, Z., Wang, H., Liu, X., Wang, X., 2004. The blown sand flux over a sandy surface: a wind tunnel investigation on the fetch effect. Geomorphology 57, 117-127.

Fang, X., Li, J., Zhou, S., Kang, S., 1998. Aeolian sand deposition in the source area of Yellow River and its significance. Acta Sedimentology Sin. 16, 40-44.

Feng, J., Wang, T., Qi, S., Xie, C., 2005. Land degradation in the source region of the Yellow River, northeast Qinghai-Xizang Plateau: classification and evaluation. Environ. Geol. 47, 459-466.

Feng, J., Wang, T., Xie, C., 2004. Land desertification in the source region of the Yellow River: northeast Qinghai-Xizang plateau. Ecol. Environ. 13, 601-604. 
Field, J.P., Belnap, J., Breshears, D.D., Neff, J.C., Okin, G.S., Whicker, J.J., Painter, T.H., Ravi, S., Reheis, M.C., Reynolds, R.L., 2010. The ecology of dust. Front. Ecol. Environ. 8, 423-430.

Field, J.P., Breshears, D.D., Whicker, J.J., Zou, C.B., 2012. Sediment capture by vegetation patches: Implications for desertification and increased resource redistribution. J. Geophys. Res. 117, G01033.

Garner, W., Steinberger, Y., 1989. A proposed mechanism for the formation of fertile islands in the desert ecosystem. J. Arid Environ. 16, 257-262.

Gibbens, R.P., Tromble, J.M., Hennessy, J.T., Cardenas, M., 1983. Soil movement in mesquite dunelands and former grasslands of southern New Mexico from 1933 to 1980. J. Range Manag. 36, 145-148.

Gillette, D.A., Pitchford, A.M., 2004. Sand flux in the northern Chihuahuan desert, New Mexico, USA, and the influence of mesquite-dominated landscapes. J. Geophys. Res. 109, F04003.

Gong, Z., Huang, R., Zhang, G., 2014. Soil Geography of China. Science Press, Beijing, pp. 636 pp.

Han, Y., Xi, X., Song, L., Ye, Y., Li, Y., 2004. Spatio-temporal sand-dust distribution in Qinghai-Tibet Plateau and its climatic significance. J. Desert Res. 24, 588-592.

Hobbs, R.J., Harris, J.A., 2001. Restoration ecology: repairing the earth's ecosystems in the new millennium. Restor. Ecol. 9, 239-246.

Immerzeel, W.W., van Beek, L.P.H., Bierkens, M.F.P., 2010. Climate change will affect the Asian water towers. Science 328, 1382-1385.

Jin, H., Li, X., Gong, J., 2003. Causes and controlling countermeasures of land desertification in the river source region of Eastern Tibetan. J. Desert Res. 23, $28-32$.

Larney, F.J., Bullock, M.S., Janzen, H.H., Ellert, B.H., Olson, E.C.S., 1998. Wind erosion effects on nutrient redistribution and soil productivity. J. Soil Water Conserv. 53 (2), 133-140.

Lavee, H., Imeson, A.C., Sarah, P., 1998. The impact of climate change on geomorphology and desertification along a Mediterranean-arid transect. Land Degrad. Dev. 9, 407-422.

Leys, J., McTainsh, G., 1994. Soil loss and nutrient decline by wind erosion-cause for concern. Aust. J. Soil Water Conserv. 7 (3), 30-40.

Li, B., 1997. The rangeland degradation in north China and its preventive strategy. Sci. Agric. Sin. 6 (2), 1-9.

Li, H., Xiao, P., Feng, X., Wan, W., Ma, R., Duan, H., 2010. Lake changes in spatial evolution and area in source region of Three Rivers in recent 30 years. J. Lake Sci. 22, 862-873.

Li, J., Cai, H., Cheng, Q., Qiao, C., Chu, H., Chen, D., Xu, S., Zhao, X., Zhao, L., 2012. Characterizing the evapotranspiration of a degraded grassland in the Sanjiangyuan Region of Qinghai Province. Acta Prataculturae Sin. 21, 223-233.

Li, J.R., Okin, G.S., Alvarez, L., Epstein, H., 2008. Effects of wind erosion on the spatial heterogeneity of soil nutrients in two desert grassland communities. Biogeochemistry 88, 73-88.

Li, J.R., Okin, G.S., Epstein, H.E., 2009. Effects of enhanced wind erosion on surface soil texture and characteristics of windblown sediments. J. Geophys. Res. 114 G02003.

Li, S., Yang, P., Wang, Y., Zhang, C., 2005. Preliminary analysis on development and driving factors of sandy desertification on Ali plateau. J. Desert Res. 25, 838-844.

Liu, J., Xu, X., Shao, Q., 2008. Grassland degradation in the three-river headwaters region, Qinghai Province. J. Geog. Sci. 18, 259-273.

Liu, J., Zhang, Z., Xu, X., Kuang, W., Zhou, W., Zhang, S., Li, R., Yan, C., Yu, D., Wu, S., Jiang, N., 2010. Spatial pattens and driving forces of land use change in China during the early 21st century. J. Geog. Sci. 20, 483-494.

Liu, L., Zhang, Y., Bai, W., Yan, J., Ding, M., Shen, Z., Li, S., Zheng, D., 2006. Characteristics of grassland degradation and driving forces in the source region of the Yellow River from 1985-2000. J. Geog. Sci. 16 (2), 131-142.

Liu, X., 2007. The investigation for degenerate grassland of degenerated meadow in Sanjiangyuan nature reserve. J. Qinghai Norm. U. (Nat. Sci.) 1, 93-96.

Livingstone, I., Warren, A., 1996. Aeolian Geomorphology-An Introduction. Addison Wesley Longman, London, pp. 211 pp.

Lyles, L., 1988. Basic wind erosion processes. Agr. Ecosyst. Environ. 22 (3), 91-101.

Lyles, L., Tatarko, J., 1986. Wind erosion effects on soil texture and organic-matter. J. Soil Water Conserv. 41 (3), 191-193.

Marticorena, B., Bergametti, G., 1995. Modeling the atmospheric dust cycle. 1. design of a soil-derived dust emission scheme. J. Geophys. Res. 100, 16415-16430.

Muller, E.N., Wainwright, J., Parsons, A.J., Turnbull, L., 2013. Patterns of Land Degradation in Drylands: Understanding Self-organized Ecogeomorphic Systems. Springer, London, pp. 3-4.

Okin, G.S., Gillette, D.A., 2001. Distribution of vegetation in wind-dominated landscapes: Implications for wind erosion modeling and landscape processes. J. Geophys. Res. 106, 9673-9683.

Okin, G.S., Painter, T.H., 2004. Effect of grain size on remotely sensed spectral reflectance of sandy desert surfaces. Remote Sens. Environ. 89, 272-280.

Okin, G.S., Gillette, D.A., Herrick, J.E., 2006. Multi-scale controls on and consequences of aeolian processes in landscape change in arid and semi-arid environments. J. Arid Environ. 65, 253-275.

Okin, G.S., Li, J., Alvarez, L., Peters, D., D'odorico, P., 2008, Feedbacks between aeolian processes, vegetation productivity, and nutrient flux in deserts. Joint Meeting of The Geological Society of America, Soil Science Society of America, American Society of Agronomy, Crop Science Society of America, Gulf Coast Association of Geological Societies with the Gulf Coast Section of SEPM, Paper No. 51-2.

Okin, G.S., Parsons, A.J., Wainwright, J., Herrick, J.E., Bestelmeyer, B.T., Peters, D.C., Fredrickson, E.L., 2009. Do changes in connectivity explain desertification? Bioscience 59, 237-244.
Park, S.U., Jeong, J.I., 2008. Direct radiative forcing due to aerosols in Asia during March 2002. Sci. Total Environ. 407, 394-404.

Peters, D.P.C., Sala, O.E., Allen, C.D., Covich, A., Brunson, M., 2007. Cascading events in linked ecological and socioeconomic systems. Front. Ecol. Environ. 5, 221-224.

Ravi, S., D'Odorico, P., Huxman, T.E., Collins, S.L., 2010. Interactions between soil erosion processes and fires: implications for the dynamics of fertility islands. Rangeland Ecol. Manage. 63, 267-274.

Ravi, S., D'Odorico, P., Wang, L.X., White, C.S., Okin, G.S., Macko, S.A., Collins, S.L 2009. Post-fire resource redistribution in desert grasslands: a possible negative feedback on land degradation. Ecosystems 12, 434-444.

Reynolds, J.F., Virginia, R.A., Kemp, P.R., de Soyza, A.G., Tremmel, D.C., 1999. Impact of drought on desert shrubs: effects of seasonality and degree of resource island development. Ecol. Monogr. 69, 69-106.

Reynolds, R., Belnap, J., Reheis, M., Lamothe, P., Luiszer, F., 2001. Aeolian dust in Colorado Plateau soils: Nutrient inputs and recent change in source. PNAS 98 7123-7127.

Schlesinger, W.H., Pilmanis, A.M., 1998. Plant-soil interactions in deserts. Biogeochemistry 42, 169-187.

Schlesinger, W.H., Raikes, J.A., Hartley, A.E., Cross, A.E., 1996. On the spatial pattern of soil nutrients in desert ecosystems. Ecology 77, 364-374.

Schlesinger, W.H., Reynolds, J.F., Cunningham, G.L., Huenneke, L.F., Jarrell, W.M., Virginia, R.A., Whitford, W.G., 1990. Biological feedbacks in global desertification. Science 247 (4946), 1043-1048.

Shao, Y., 2008. Physics and Modelling of Wind Erosion. Springer, Berlin.

Soderberg, K., Compton, J.S., 2007. Dust as a nutrient source for fynbos ecosystems, South Africa. Ecosystems 10, 550-561.

Sterk, G., Hermann, L., Bationo, A., 1996. Wind-blown nutrient transport and soil productivity changes in southwest Niger. Land Degrad. Dev. 7 (4), 325-335.

UNEP (United Nations Environmental Programme), 1992. World Atlas of Desertification. In: Middleton, N., Thomas, D. (Eds.), Edward Arnold, London.

Uno, I., Eguchi, K., Yumimoto, K., Takemura, T., Shimizu, A., Uematsu, M., Liu, Z., Wang, Z., Hara, Y., Sugimoto, N., 2009. Asian dust transported one full circuit around the globe. Nat. Geosci. 2 (8), 557-560.

Wang, G., Cheng, G., 2001. Characteristics of grassland and ecological changes of vegetations in the source regions of Yangtze and Yellow Rivers. J. Desert Res. 21 (2), 101-107.

Wang, G., Guo, X., Cheng, G., 2002. Dynamic variations of landscape pattern and the landscape ecological functions in the source area of the Yellow River. Acta Ecol. Sin. 22, 1587-1598.

Wang, G., Qian, J., Cheng, G., Lai, Y., 2001. Eco-environmental degradation and causal analysis in the source region of the Yellow River. Environ. Geol. 40 (7), 884-890.

Wang, S., Zhou, C., Li, K., Zhu, S., Huang, F., 2000. Analysis on spatial distribution characteristics of soil organic carbon reservoir in China. Acta Geogr. Sin. 55, 533-544.

Wang, X., 2013. Sandy desertification: borne on the wind. Chin. Sci. Bull. 58, 23952403.

Wang, X., Chen, F., Dong, Z., 2006. The relative role of climatic and human factors in desertification in semiarid China. Global Environ. Change 16, 48-57.

Wang, X., Chen, F., Hasi, E., Li, J., 2008. Desertification in China: an assessment. Earth-Sci. Rev. 88, 188-206.

Wang, X., Dong, Z., Zhang, J., Liu, L., 2004. Modern dust storms in China: an overview. J. Arid Environ. 58, 559-574.

Wang, X., Hasi, E., Zhou, Z., Liu, X., 2007. Significance of variations in the wind energy environment over the past 50 years with respect to dune activity and desertification in arid and semiarid northern China. Geomorphology 86, 252 266.

Wang, X., Lang, L., Hua, T., Wang, H., Zhang, C., Wang, Z., 2012. Characteristics of the Gobi desert and their significance for dust emissions in the Ala Shan Plateau (Central Asia): an experimental study. J. Arid Environ. 81, 35-46.

Wang, X., Ma, W., Lang, L., Hua, T., 2014. Controls on desertification during the early 21 st century in the Water Tower region of China. Reg. Environ. Change doi: http://dx.doi.org/10.1007/s10113-014-0661-5.

Wang, X., Wang, G., Lang, L., Hua, T., Wang, H., 2013. Aeolian transport and sandy desertification in semiarid China: a wind tunnel approach. Land Degrad. Dev. 24 , 605-612.

Webb, N.P., Strong, C.L., Chappell, A., Marx, S.K., McTainsh, G.H., 2013. Soil organic carbon enrichment of dust emissions: magnitude, mechanisms and its implications for the carbon cycle. Earth Surf. Processes Landforms 38 (14), $1662-1671$

Wen, L., Dong, S., Zhu, L., Shi, J., Liu, D., Wang, Y., Ma, Y., 2011. The effect of natural factors and disturbance intensity on spacial heterogeneity of plant diversity in alpine meadow. Acta Ecol. Sin. 31, 1844-1854.

Wessels, K.J., Prince, S.D., Reshef, I., 2008. Mapping land degradation by comparison of vegetation production to spatially derived estimates of potential production. J. Arid Environ. 72, 1940-1949.

Wu, Z., 2009. Chinese Deserts and its Combating. Science Press, Beijing.

Yan, Z., Zhou, H., Liu, W., Zhou, L., 2003. Preliminary discuss on grassland degradation in the source region of Yangtze and Yellow Rivers. Grassland China 25, 73-78.

Yang, J., Ding, Y., Chen, R., 2006. Spatial and temporal of variations of alpine vegetation cover in the source regions of the Yangtze and Yellow Rivers of the Tibetan Plateau from 1982 to 2001. Environ. Geol. 50, 313-322.

Zhang, Y., Li, B., Zheng, D., 2002. A discussion on the boundary and area of the Tibetan Plateau in China. Geogr. Res. 21, 1-8. 
Zhang, Y., Liu, L., Bai, W., Shen, Z., Yan, J., Ding, M., Li, S., Zheng, D., 2006. Grassland degradation in the source region of the Yellow River. Acta Geogr. Sin. 61 (1), 3-14.

Zheng, Y.M., Zhang, H.Y., Niu, Z.G., Gong, P., 2012. Protection efficacy of national wetland reserves in China. Chin. Sci. Bull. 57, 1116-1134.

Zhu, Z., 1986. Phenomena of blownsands and their impacts on lands in humid and subhumid zones. J. Desert Res. 6 (4), 1-13.
Zhu, Z., Cui, S., 1996. The problem of desertification in South China. J. Desert Res. 16, 331-337.

Zobeck, T.M., Fryrear, D.W., Pettit, R.D., 1989. Management effects on wind-eroded sediment and plant nutrients. J. Soil Water Conserv. 44, 160-163.

Zou, X.Y., Li, S., Zhang, C.L., Dong, G.R., Dong, Y.X., Yan, P., 2002. Desertification and control plan in the Tibet Autonomous Region of China. J. Arid Environ. 51, 183198. 